\title{
Delimitação das áreas de preservação permanente no município de Monte Azul/MG
}

\author{
Delimitation of permanent preservation areas in the city of Monte Azul,MG \\ Fernando Hiago Souza Fernandes', Adriana Aparecida Moreira ${ }^{2}$, André de Oliveira Costa ${ }^{3}$, \\ César Vinícius Mendes Nery ${ }^{4}$ \\ ' Engenheiro Ambiental. Mestrando em Geociências Aplicadas - UnB, Brasília, DF - Brasil. \\ ${ }^{2}$ Engenheira Ambiental. Mestranda em Sensoriamento Remoto - UFRGS, Porto Alegre, RS - Brasil. \\ ${ }^{3}$ Engenheiro Ambiental pelas Faculdades Santo Agostinho - FACET, Montes Claros, MG - Brasil. \\ ${ }^{4}$ Professor M.Sc. das Faculdades Santo Agostinho, Doutorando em Geografia, PUC Minas, Montes Claros, MG - Brasil.
}

\begin{abstract}
Resumo
O presente trabalho tem como objetivo identificar as áreas de preservação permanente em topos de morro e nas faixas marginais dos cursos hídricos do município de Monte Azul/MG embasadas pela Lei Federal de n 12.651/12 (BRASIL, 2012). A escolha deste município partiu do princípio da inexistência de tais áreas delimitadas por parte do poder público municipal. A metodologia utilizada para realização da identificação das APP em topos de morro baseou-se no estudo desenvolvido por Cortizo (2007) identificando a cota de maior depressão, caracterizada pela localização da base do morro, já as áreas de preservação em cursos hídricos foram identificadas por meio da criação de um Buffer de 30 metros nos recursos hídricos disponibilizados pelo Zoneamento Ecológico do Estado de Minas Gerais (ZEE, 2013). Os resultados da delimitação das áreas de preservação permanente em topos de morro e nas faixas marginais de cursos d'água no município de Monte Azul/MG correspondem a uma área de $73,87 \mathrm{Km}^{2}$, sendo as APP ao longo dos cursos hídricos responsáveis por 6,92\% e as áreas de preservação em topos de morro com $0,51 \%$ de toda a área do município.
\end{abstract}

Palavras-chaves: Área de Preservação. Rios. Topos de Morro. Legislação ambiental.

\begin{abstract}
This paper aims to identify the hilltop permanent preservation areas and marginal bands of Monte Azul/MG watercourses the based on \#12.651/12 (BRASIL, 2012) Federal Law. This city choice was made based upon the delimitation inexistence of such areas by the municipal government. The methodology used to conduct the identification of hilltop PPA was based on the paper developed by Cortizo (2007) identifying the highest depression quota, characterized by the location of the base of the hill; the preservation areas in watercourses were identified through the creation of a 30 meters water resources buffer made available by the Ecological Zoning of the State of Minas Gerais (ZEE, 2013). The results of the delineation of permanent preservation areas on hilltops and in watercourses bands in the city of Monte Azul/MG corresponds to an area of $73,87 \mathrm{~km}^{2}$, being the PPA along the watercourses responsible for $6,92 \%$ and the hilltop permanent preservation areas with $0,51 \%$ of the whole city area.
\end{abstract}

Keywords: Area of preservation. Rivers. Hilltop. Environmental Legislation. 


\section{INTRODUÇÃO}

Nas últimas décadas a sociedade tem se preocupado cada vez mais com as questões ambientais, uma vez que as alterações de ecossistemas por meio da fragmentação e substituição por ecossistemas antrópicos podem não só reduzir a biodiversidade, mas também alterar de maneira significativa o funcionamento dos sistemas naturais (FAHRIG, 2003; MOREIRA et al., 2008).

Aliado ao exposto acima, foi criado no Brasil o primeiro código florestal brasileiro regulamentado pela Lei Federal de n ${ }^{\circ} 4.771$ de 1965 (BRASIL, 1965), recentemente revogada pela Lei Federal de $\mathrm{n}^{\mathrm{0}} 12.651$ de 2012 , que dispõe sobre a proteção da vegetação nativa e demais formas de vegetação presente no território brasileiro. Assim, o novo código florestal define em seu artigo $3^{\circ}$, inciso II, ás Áreas de Preservação Permanente - APP como: área protegida, coberta ou não por vegetação nativa, com a função ambiental de preservar os recursos hídricos, a paisagem, a estabilidade geológica e a biodiversidade, facilitar o fluxo gênico de fauna e flora, proteger o solo e assegurar o bem-estar das populações humanas (BRASIL, 2012).

Ainda que protegidas por uma legislação federal e da sua grande importância para o meio ambiente, as áreas de preservação permanente vêm sofrendo diversas alterações em suas fisionomias, em virtude de atividades agropecuárias praticada sobre o meio e do crescimento desordenado das áreas urbanas (ODUM, 1988). Neste contexto, torna-se imprescindível a utilização de ferramentas capazes de identificar e monitorar essas áreas em função da sua importância ambiental, paisagística e ecológica.

Todavia, considerando um país de dimensões continentais como o Brasil, torna-se difícil à caracterização e a consolidação dessas áreas em cartas topográficas e mapas temáticos, para orientação das ações em campo, sejam elas em âmbito regional ou nacional (HOTT et al., 2005).

Neste sentido, as geotecnologias têm sido apresentadas como uma opção para a caracterização e determinação de limites propostos pelas legislações ambientais vigentes (PONZONI et al., 2012), sendo possível a delimitação automática dessas áreas, tornando-se um meio viável de monitoramento de áreas de preservação ambiental (HOTT et al., 2004). Entretanto, existe uma visível dificuldade em consolidar a lei 12.651/2012 em termos de mapeamento das áreas de preservação permanente em topos de morro, montanhas e linhas de cumeada, uma vez que na Resolução Conama 303/02 (BRASIL, 2002), privilegia-se o reconhecimento em campo (HOTT et al., 2005).

Em estudos realizados (Nery et al., 2013; Hupp e Fortes, 2013; Pasa et al., 2103; Oliveira e Fernandes Filho, 2013; Lima et al., 2012; Hott et al., 2005) verifica-se resultados satisfatórios em pequenas e extensas áreas de estudos, quando aplicado as geotecnologias para identificação das APP em topo de morro.

Assim o objetivo deste trabalho foi identificar duas categorias de áreas de preservação permanente no município de Monte Azul/MG, topos de morro e recursos hídricos aplicando o novo código florestal brasileiro, por meio da utilização das técnicas do geoprocessamento.

\subsection{REFERENCIAL TEÓRICO}

Em virtude da sua função ambiental as APP precisam ser mantidas com suas características originais, recuperadas e reconhecidas como indispensáveis para a sustentabilidade dos agroecossistemas e bacias hidrográficas, e por consequência, da vida humana saudável e seu desenvolvimento sustentável.

Como reflexo da importância das áreas de preservação permanente para o território brasileiro, considera-se para efeito da Lei Federal de $\mathrm{n}^{\mathrm{o}}$ 12.651/12 (BRASIL, 2012) em seu artigo $4^{\mathrm{o}}$, inciso I, as áreas de preservação permanente ao longo das faixas marginais de qualquer curso d'água natural, desde a borda da calha do leito regular com largura mínima de trinta metros, determinado na alínea "a" as APP para os cursos d'água de menos de dez metros de largura.

Segundo Skorupa (2003), as APP ao longo dos cursos hídricos apresentam papel fundamental para a preservação dos rios, lagos e represas, pois a vegetação presente tende atenuar o assoreamento por sedimentos carreados pelas chuvas, mantém o ambiente com temperaturas amenas e servem como corredores ecológicos para fauna. No entanto, as matas ciliares dos cursos hídricos são normalmente retiradas pelos agricultores, uma vez que nessas áreas o solo se apresenta com uma maior quantidade de material orgânico, caracterizando assim como áreas férteis (MARTINS et al., 2013). 
Em se tratando de topos de morros a Lei Federal de $\mathrm{n}^{\circ}$ 12.651/12 considera como APP no inciso IX os topos de morros, montes, montanhas e serras, com altura mínima de cem metros e inclinação média maior que $25^{\circ}$, as áreas delimitadas a partir da curva de nível correspondente a $2 / 3$ (dois terços) da altura mínima da elevação sempre em relação à base, sendo esta definida pelo plano horizontal determinado por planície ou espelho d'água adjacente ou, nos relevos ondulados, pela cota do ponto de sela mais próximo da elevação (BRASIL, 2012).

De acordo Nery et al. (2013), a manutenção de vegetação em topo de morros ou montanhas é de ampla importância, pois o aumento da demanda por áreas urbanas pode acarretar em apropriações indevidas nesses locais. Essa atitude leva por consequência o desmatamento da vegetação nativa, que certamente ocasionará em possíveis desmoronamentos e deslizamento de terra, pois a desestruturação do solo torna-o mais susceptível a eventos dessa natureza (WEISS, 2012).

Para Campos (2009), os topos de morros configuram-se como dispersores de águas de uma determinada região, sendo ainda elementos da paisagem caracterizados por seus cumes, apresentando em contrapartida vales, caracterizados pelas baixas altitudes.

As Resoluções CONAMA n ${ }^{\circ} .303$ (CONAMA, 2002) e Resolução CONAMA nº 369 (CONAMA, 2006) também prescrevem os limites e usos destas áreas que recobrem as nascentes e margens dos rios e as florestas que ocupam locais íngremes e topos de morros, que juntas formam as APP.

As APP estão localizadas especialmente em áreas frágeis e de interesse público encontradas nas imediações e cursos d'água, nas lagoas, lagos ou reservatórios d'água natural ou artificiais, nos topos de morros montanhas e serras, nas encostas com aclive acentuado, nas restingas na faixa litorânea, as vegetações localizadas em altitudes superiores a 1.800 metros e as vegetações localizadas em determinadas áreas urbanas (BRASIL, 2012).

Desta forma, percebe-se que as APP, não se restringe á uma única modalidade de área, mas a todo tipo que apresente vulnerabilidade ecológica, a fim de assegurar o uso sustentável das florestas em harmonia com a promoção do desenvolvimento sustentável.

\section{MATERIAIS E MÉTODOS}

\section{1 Área de Estudo}

O município de Monte Azul possui uma área territorial de 994,23 km² (IBGE, 2010) e este se

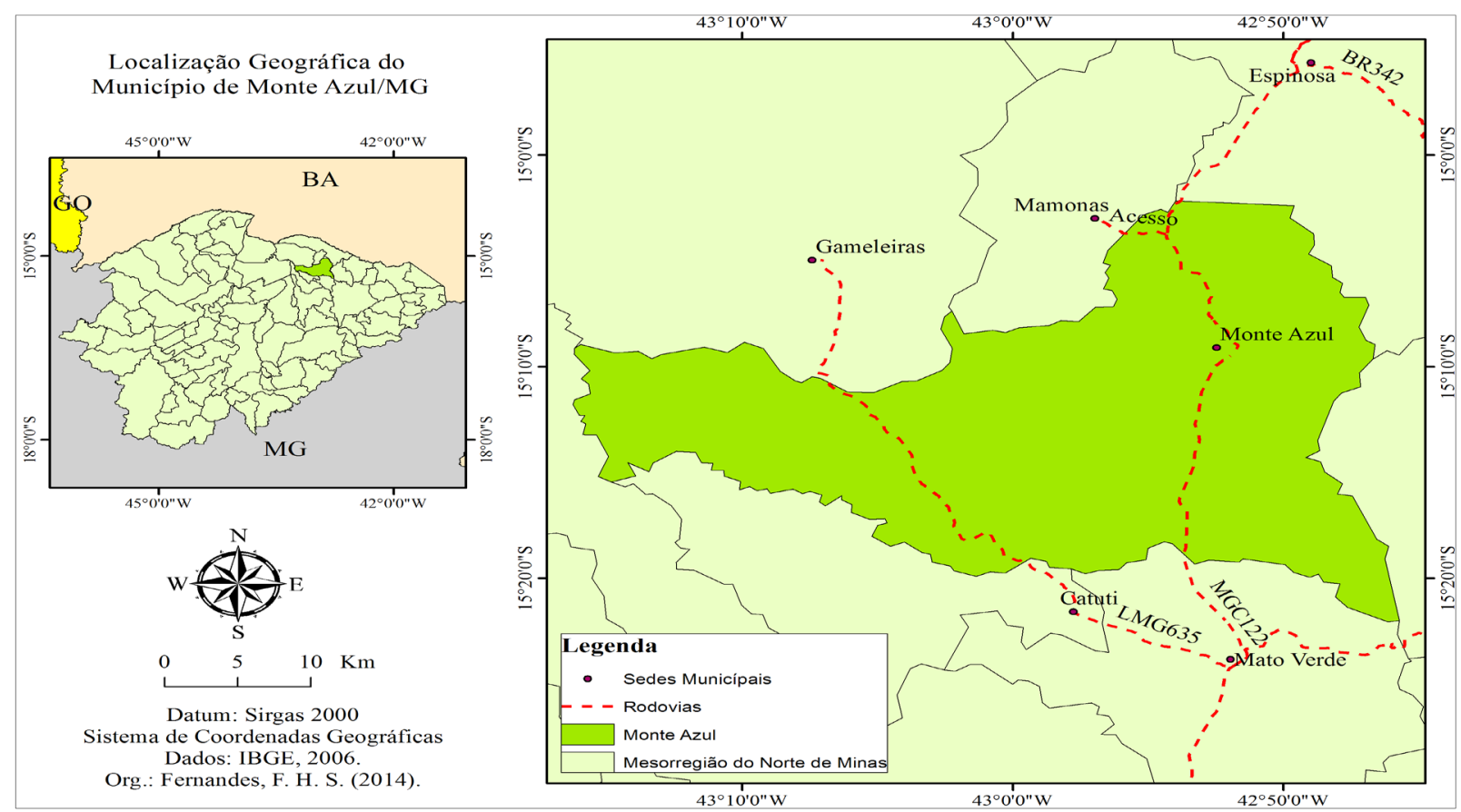

Figura 01 - Localização geográfica de Monte Azul, MG

Fonte: Próprio Autor 
encontra localizado ao norte do estado de Minas Gerais, entre as coordenadas $15^{\circ} 00^{\prime} 00 \mathrm{~N}$ e $15^{\circ} 30^{\prime}$ $00 \mathrm{~W}$ de latitude e $43^{\circ} 25^{\prime} 00 \mathrm{~S}$ e $42^{\circ} 40^{\prime} 00 \mathrm{~W}$ de longitude conforme Figura 1.

De acordo com o censo demográfico de 2010 o município de Monte Azul possui um total de 21.994 habitantes sendo a base de sua economia movida por diversos setores de serviços, da indústria e pecuária (IBGE, 2010). A região de estudo possui clima classificado como Aw - tropical com inverno seco e estações chuvosas no verão de acordo com a classificação de Köppen. A temperatura média mensal da região mais fria é superior a $18^{\circ} \mathrm{C}$. Suas formas vegetais apresentam características do tipo Savana/Floresta Estacional (KNAUER et al., 2007), sendo o cerrado o bioma predominante do município (IBGE, 2004).

\subsection{Base de dados}

Para atingir aos objetivos desse trabalho, foram utilizados dados altimétricos e de declividade respectivamente das folhas 15S435_ZN e 15S435_SN (Figura 2), do projeto TOPODATA disponibilizado pelo Instituto Nacional de Pesquisas Espaciais (INPE) derivado do modelo SRTM (VALERIANO, 2005). As imagens foram processadas no software SPRING 5.2.6 Câmara et al. (1996), com sistema de coordenadas, latitude e longitude e modelo de terra, SIRGAS 2000.

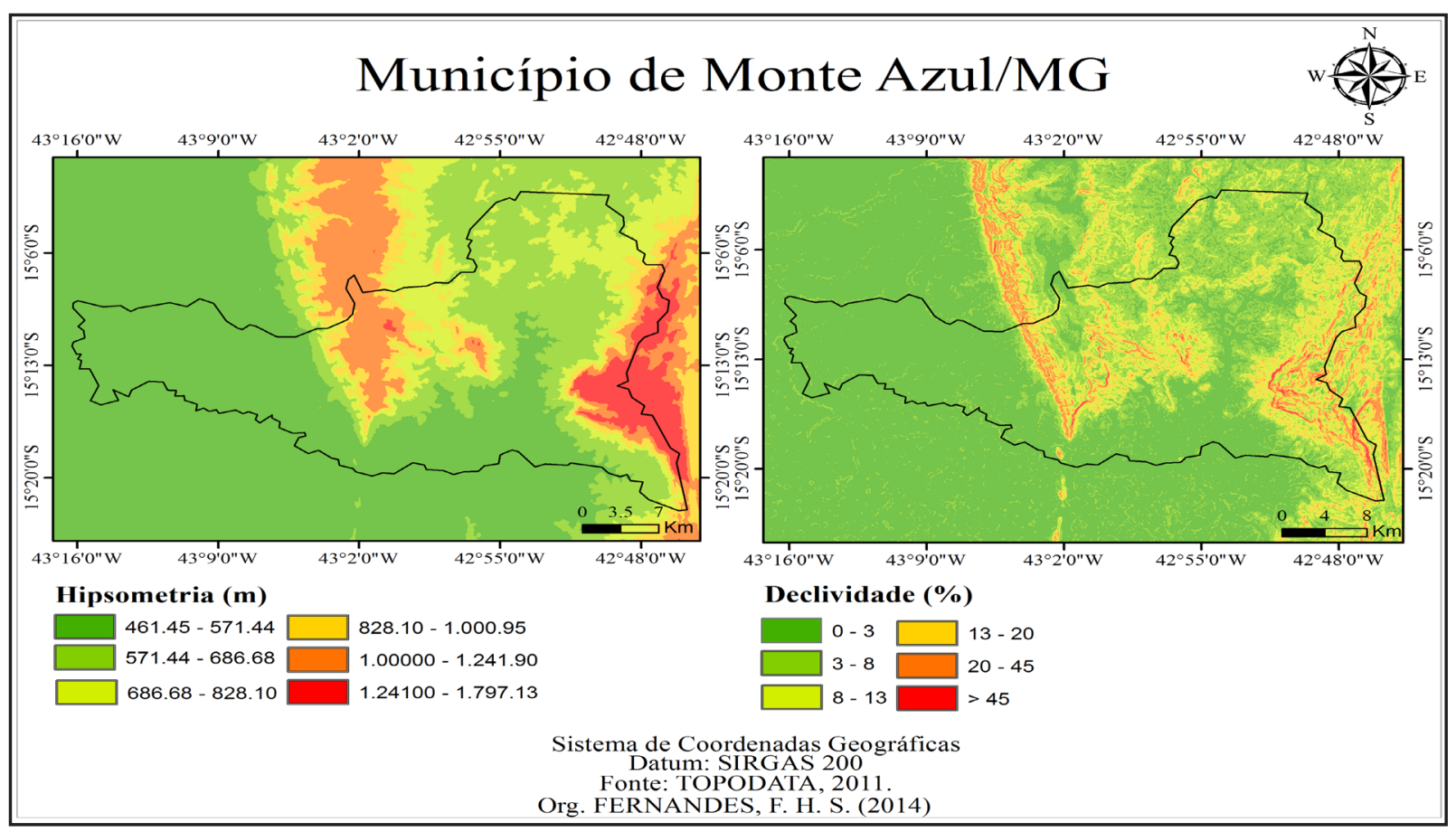

Figura 02 - Mapa hipsométrico e de declividade do município de Monte Azul/MG

Fonte: Próprio Autor

Para delimitação das áreas de preservação permanente em topos de morro foram realizados dois processamentos digitais, um por meio do fatiamento de classes criando uma categoria temática contendo as declividades relacionadas $\left(0-25^{\circ}, 25-100^{\circ}\right)$ e outro a partir da extração das curvas de nível com equidistância de 10 metros da folha altimétrica. A partir da ferramenta extração de topo de morros do SPRING (CAMARA et al., 1996), foram identificadas as APP em topos de morro dispostas pelo artigo $4^{\circ}$ da Lei Federal de $n^{\circ}$ 12.651/12 (BRASIL, 2012) que define os seguintes parâmetros, abaixo.

- Altura mínima dos morros, montanhas e serras superior a cem metros;

- Inclinação média maior de $25^{\circ}$;

- áreas delimitadas por curvas de nível correspondente a 2/3 (dois terços) da altura mínima.

O parâmetro utilizado para definição do topo foi considerado a cota de maior depressão, caracterizada pela localização da base do morro ou montanha, identificada como ponto de sela (CORTIZO, 2007), conforme (Figura 3). 


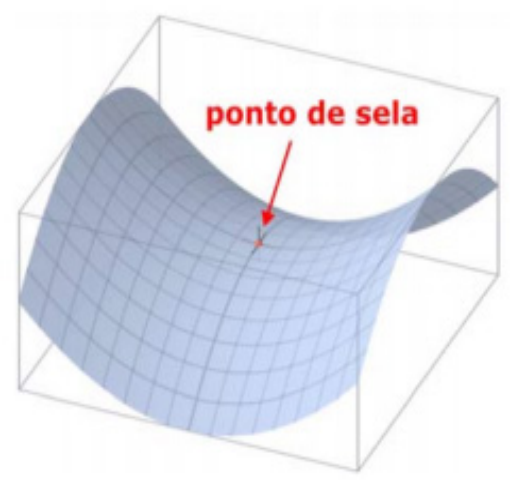

(A)

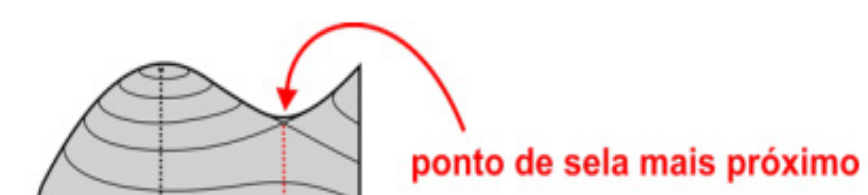

mapa de isolinhas ou curvas de nivel

Figura 03 - (A) Forma geométrica típica de um ponto de sela e (B) Representação da superfície matemática correspondente a uma elevação do terreno

Fonte: Adaptado de Cortizo (2007)

O mapeamento das APP nos cursos d'água foram efetuados utilizando-se o layout do software ArcGis 10.1 sob licença do laboratório de Topografia e Geoprocessamento (LABGEO) da Faculdade de Ciências Exatas e Tecnológicas Santo Agostinho (FACET), a partir da ferramenta Multiple Ring Buffer, onde gerou se um buffer de 30 metros sobre os dados da malha hídrica do município de Monte Azul, disponibilizada pelo Zoneamento Ecológico Econômico (ZEE) do estado de Minas Gerais. Este procedimento foi realizado por que a malha hídrica pertencente ao município de Monte Azul não apresentou largura superior a dez metros, conforme verificado nas imagens do Google Earth, assim foi delimitado as matas ciliares com uma distância de trinta metros com base na definição da alínea "a" do artigo $4^{\circ}$ da Lei 12.651/12 (BRASIL, 2102).

\section{RESULTADOS E DISCUSSÃO}

Com base na metodologia descrita foram delimitadas e quantificadas 2 categorias de áreas de preservação permanente no município de Monte Azul/MG. As APP em topos de morro, montes, montanhas e serras e as áreas em torno de cursos d'água.

As APP em topos de morro são representadas por uma área de 5,05 $\mathrm{Km}^{2}$ do município (Figura 4) sendo encontrada na região leste, boa parte dessas áreas de preservação, uma vez que, nessa área encontra-se a Serra do Espinhaço, prevalecendo as cotas de maiores altitudes do município (Figura 2).

Segundo Nery et al. (2013), as APP em topos de morro encontram se distribuídas em sua maior parte sobre a linha de cumeada do limite das bacias hidrográficas. Tal situação foi verificada por este estudo, uma vez que, na região leste do limite geográfico do município de Monte Azul encontra-se a Serra do Espinhaço (Figura 4), considerada como um grande divisor hidrográfico interposto entre a bacia do Atlântico Leste e a do rio São Francisco (ANA, 2006). Outra região que pode ser verificado com uma grande representatividade das APP em topos de morro foi o noroeste do município denominado como Serra Geral, onde se encontra o maior parque do gênero Estadual de Minas Gerais o Caminhos dos Gerais, criado no ano de 2007 (IEF, 2007).

Vale ressaltar que e o manancial responsável pelo abastecimento de água da cidade de Monte Azul (Figura 5), assim como os principais cursos hídricos existentes no município possui suas nascentes localizadas nas regiões da Serra do Espinhaço e Serra Geral onde se concentra um grande número 


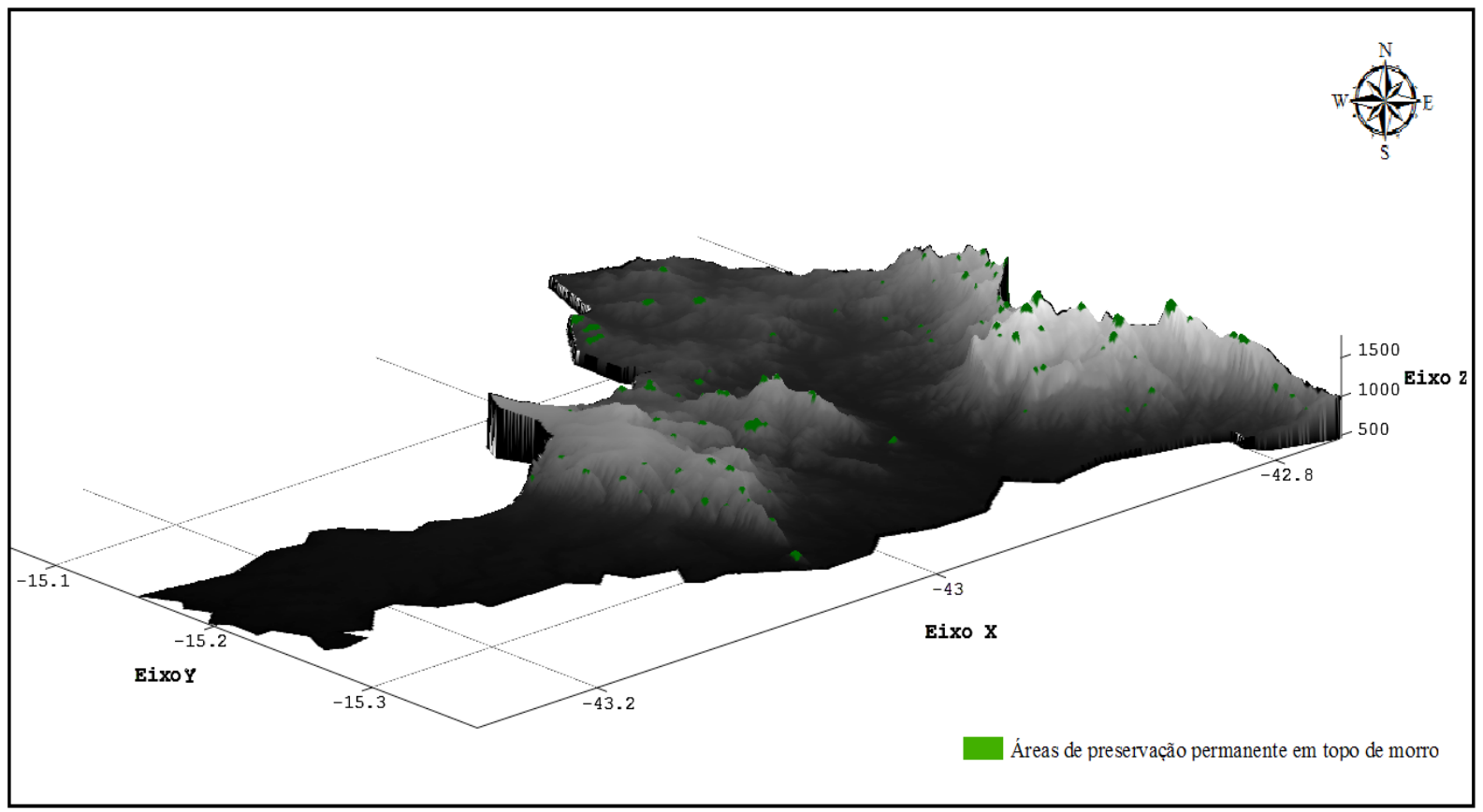

Figura 04 - APP em topo de morro situadas no município de Monte Azul/MG

Fonte: Próprio Autor

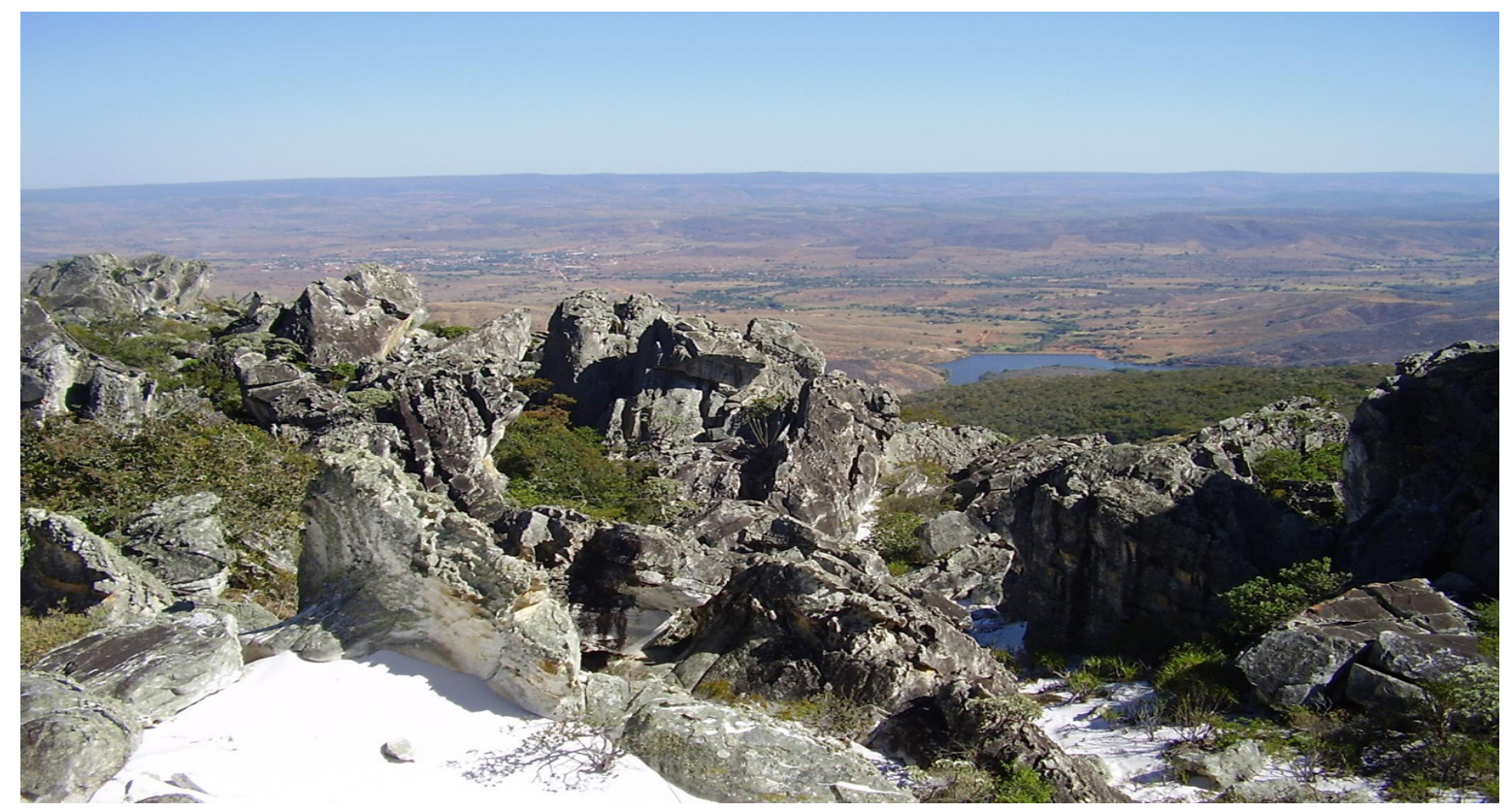

Figura 05 - Vista panorâmica da barragem de Monte Azul/MG do alto da Serra do Espinhaço.

Fonte: Arquivo fotográfico - Arisbaldo (2011).

de APP em topos de morro, desta forma, a delimitação dessas áreas são essenciais a fim de manter a integridade das mesmas, pois a preservação da vegetação em encostas acentuadas promove a estabilidade do solo pelo emaranhado de raízes das plantas, evitando perda de solo por erosão e protegendo as partes mais baixas do terreno, como as estradas e os cursos d'água; além de proteger quanto ao risco de deslizamentos e desmoronamentos, o que afetará as partes baixas do terreno (VALLER JR. et al., 2011; SKORUPA, 2003).

Em se tratando das áreas de preservação permanente nas margens dos cursos hídricos essas áreas apresentam um valor significativo, sendo 6,92\% da área total do município de Monte Azul 
representadas por esta categoria, conforme a (Figura 6).

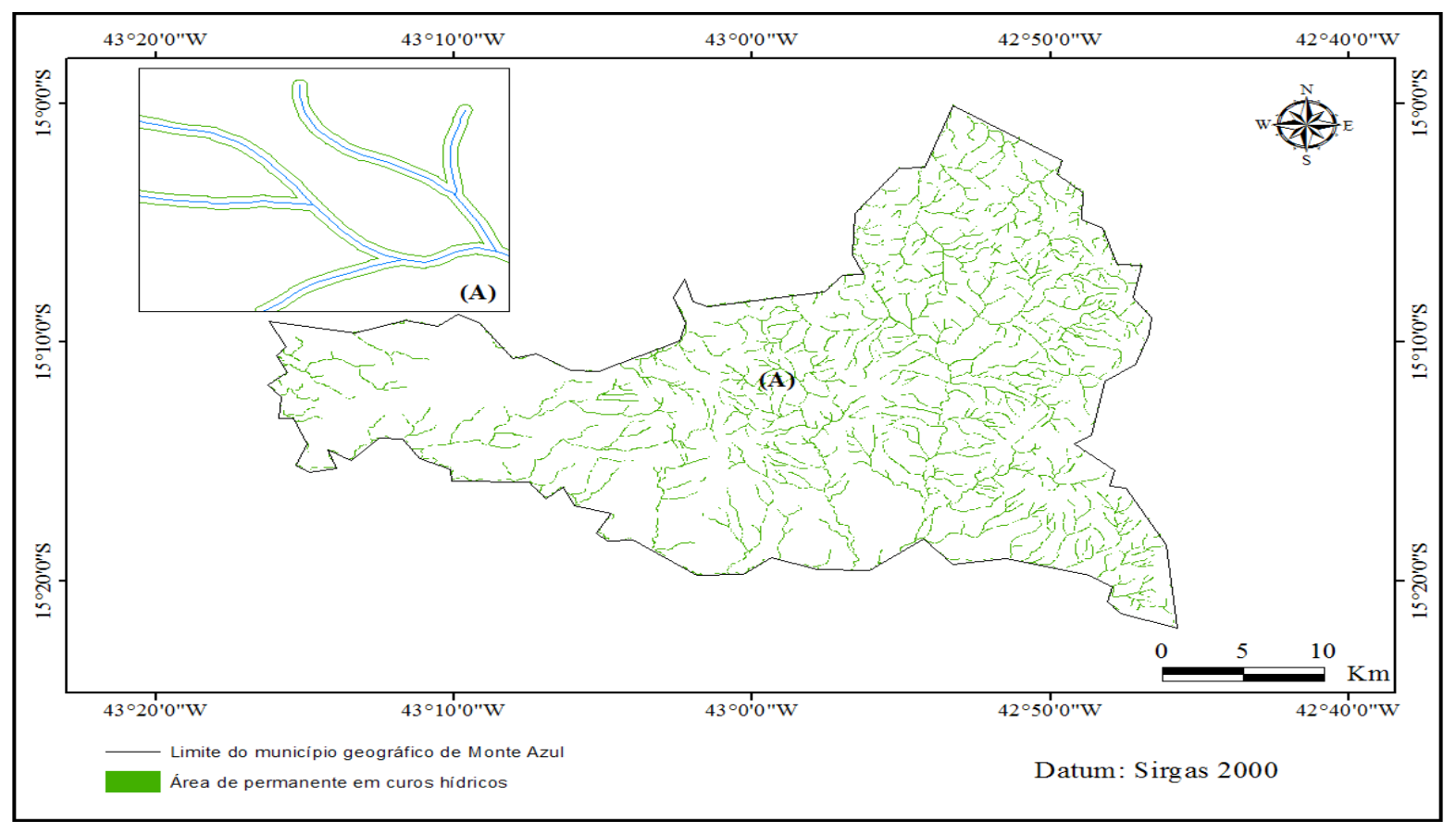

Figura 06 - Áreas de preservação permanente nas faixas marginais dos cursos hídricos no município de Monte Azul/MG.

Fonte: Próprio Autor.

Por meio da Figura acima pode perceber que as matas ciliares dos cursos hídricos do município de Monte Azul encontram-se distribuídas ao longo da fisiográfia de seu limite geográfico. No entanto, na região oeste e sul onde prevalecem áreas de declividade inferior a 3\% e com altitudes abaixo dos 572 metros (Figura 2) verifica-se uma maior escassez dos cursos hídricos (Figura 6).

Para Sousa et al. (2007), a legislação brasileira reconhece as APP de cursos hídricos como um agente regulador da vazão fluvial, consequentemente das cheias, preservadora das condições sanitárias para o desenvolvimento da vida humana nas cidades. Neste contexto, é preciso que as APP dos cursos hídricos sejam delimitadas e preservadas, pois a degradação das matas ciliares contribui para o assoreamento dos cursos d'água, elevação da turbidez da água e erosão das margens dos cursos hídricos, transportando substâncias poluidoras como defensivos e fertilizantes agrícolas (GUIMARÃES e CARVALHO, 2013; VALLER JR. et al., 2011).

As áreas de preservação permanente ao longo das faixas marginais e em topos de morro corresponderam a 7,42\% da área total do município de Monte Azul/MG, conforme a tabela 1, abaixo.

Tabela 01. Áreas de preservação permanente em topo de morro e rios.

\begin{tabular}{c|c}
\hline Categoria APP & Área (\%) \\
\hline Rios & 6,92 \\
Topo de Morro & 0,51 \\
\hline
\end{tabular}

Dentre as APP identificadas nesse trabalho, a maior participação correspondeu às APP situadas em rios com margem inferiores a $10 \mathrm{~m}$ de largura, apresentando $6.882,50$ ha de área a serem preservadas.

Para melhor visualização dos resultados das APP em topos de morro e faixas marginais de rios delimitadas pelos sistemas de informações geográficas (SIG) embasados pelo novo código florestal brasileiro, elaborou-se um mapa da distribuição das áreas de preservação permanente em topos de 


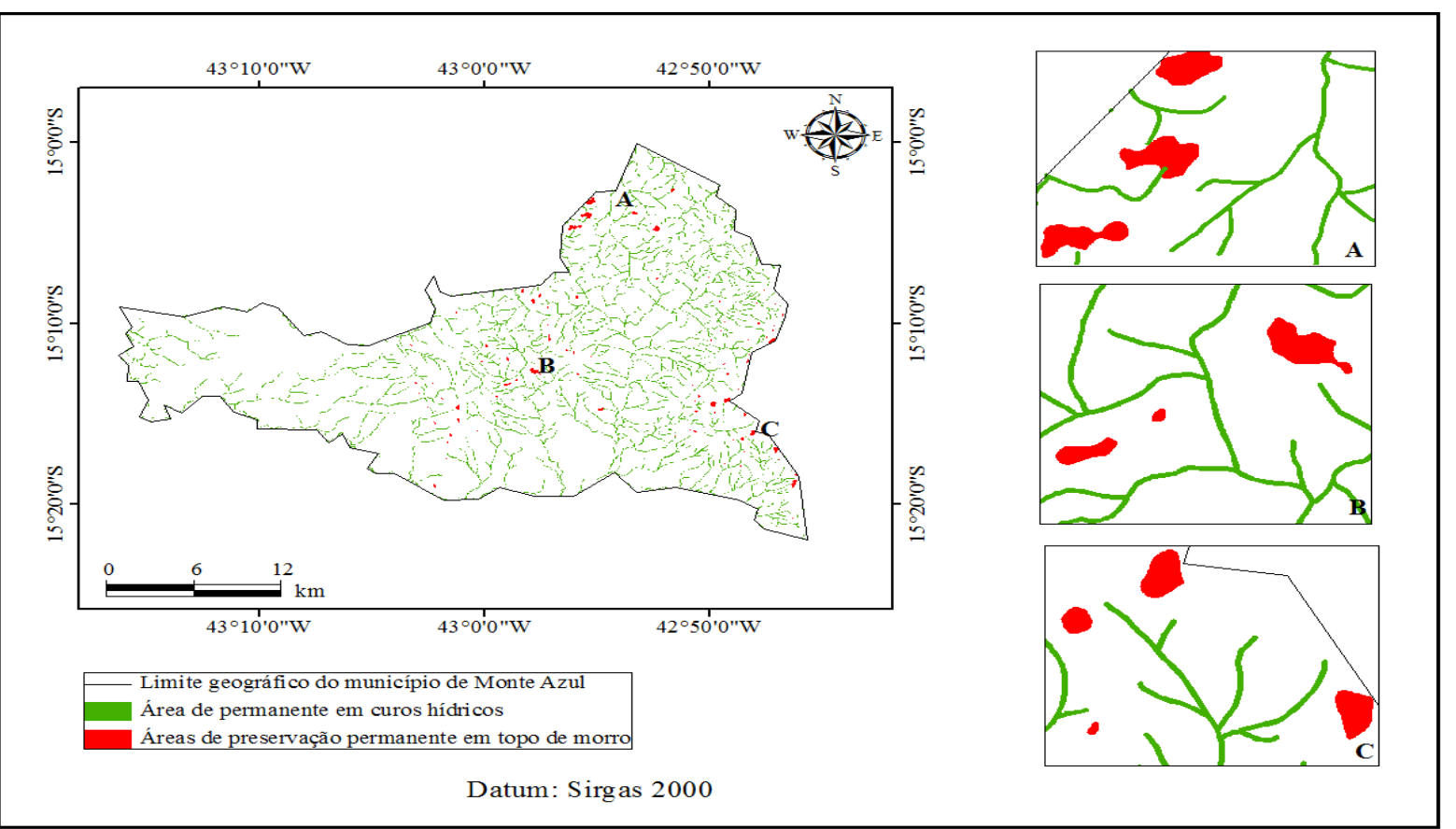

Figura 07 - Distribuição das áreas de preservação permanente em topos de morro e rios do município de Monte Azul/MG Fonte: Próprio Autor

morro e rios do município de Monte Azul/MG (Figura 7).

Vale destacar, que o município de Monte Azul encontra-se em uma região semi-árida, sendo a maior parte do ano com ausência de precipitação (Figura 8). De fato a realidade do Norte do Estado de Minas Gerais apresenta essa realidade climática que influencia no baixo padrão de vida que a população vive, pois acarretam diversos problemas como a difícil produção agrícola, a manutenção de sistemas produtivos e a ocupação e convivência com a seca (MAIA et al., 2010).

Assim, manter a integridade das áreas de preservação permanente de cursos hídricos e topos

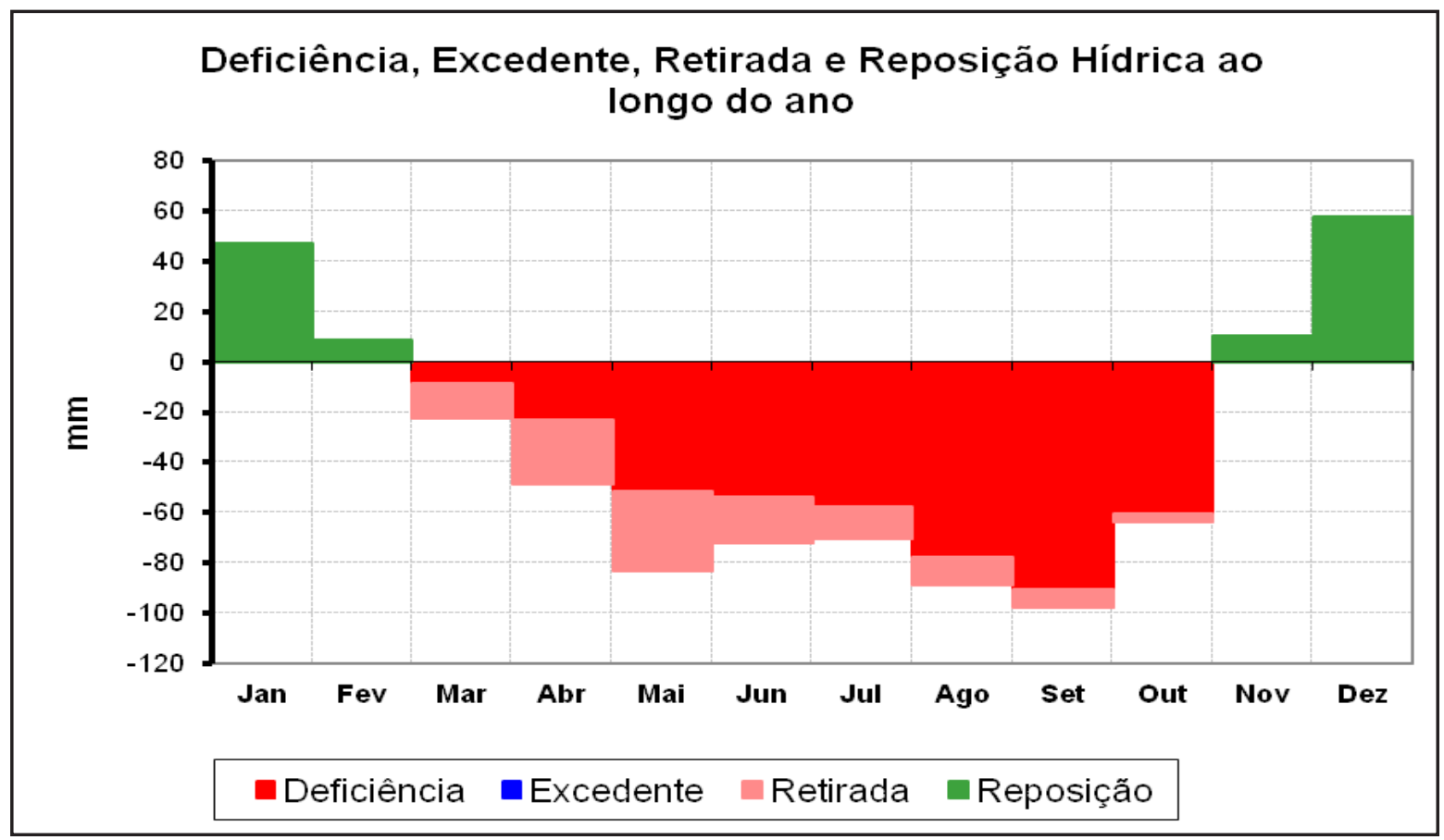

Figura 08 - Dados pluviometricos do município de Monte Azul/MG

Fonte: Próprio Autor 
de morro delimitadas por este estudo no município de Monte Azul conforme a Lei Federal de ${ }^{\circ}$ 12.651/12 (BRASIL, 2012) é de fundamental importância, uma vez que as APP ajudem no controle hidrológico das bacias hidrográficas, regulando o fluxo de água superficial e subsubperficial, e assim do lençol freático, garantindo uma melhor qualidade e quantidade da água disponível no município.

\section{CONCLUSÃO}

Por meio da utilização das ferramentas das geotecnologias pode ser determinar as áreas de preservação permanente nas mediações dos cursos hídricos e nas áreas de topos de morros do município de Monte Azul.

De acordo com as áreas de preservação identificadas verificou se que as APP dos cursos hídricos apresentam distribuídas espacialmente por todo o município, já as áreas de preservação de topos de morro encontram-se em uma forma mais aglomerada, apresentando desta forma que o município é caracteriza por uma região mais plana e com altitudes amenas. Vale salientar que os dados obtidos a respeito das APP em topos de morro requerem estudos "in loco" para avaliação dos mesmos, podendo dessa maneira serem utilizados como análise prévia de forma a viabilizar custos para caracterização dessas áreas.

Neste contexto, os órgãos públicos com interesses na área de estudo dispõem agora de base de dados sobre a localização das áreas de preservação permanente em topos de morro e nos cursos hídricos de Monte Azul. Assim sugere que estudos de caráter do uso e ocupação do solo sejam realizados nestas áreas de forma a verificar a atual situação quanto a legislação ambiental pertinente.

\section{AGRADECIMENTOS}

Os autores agradecem ao CNPq e a CAPES pelo apoio a pesquisa científica.

\section{REFERÊNCIAS}

ANA, Agência Nacional das Águas. Regiões Hidrográficas. Disponível em: < file:///C:/Users/Home/Downloads/REGIAO_HIDROGRAFICA_DO_SAO_FRANCISCO.pdf>. Acesso em: 02 jul. 2014.

BRASIL. Lei $\mathrm{n}^{\circ}$. 12.651, de 25 de maio de 2012. Dispõe sobre a proteção da vegetação nativa; altera as Leis nos 6.938, de 31 de agosto de 1981, 9.393, de 19 de dezembro de 1996, e 11.428, de 22 de dezembro de 2006; revoga as Leis nos 4.771, de 15 de setembro de 1965, e 7.754, de 14 de abril de 1989, e a Medida Provisória no 2.166-67, de 24 de agosto de 2001; e dá outras providências. Diário Oficial [da República Federativa do Brasil], Brasília, 25 maio 2012. Disponível em: < http://www.planalto.gov.br/ccivil_03/_Ato2011-2014/2012/Lei/ L12651.htm\#art83>. Acesso em: 18 jul. 2014.

BRASIL, Lei n ${ }^{\circ} 4.771$, de 16 de setembro de 1965. Institui o Novo código Florestal. Revogado pela Lei n ${ }^{\circ} 12.651$, de 2012. Diário Oficial [da República Federativa do Brasil], Brasília, 16 set. 1965. Disponível em: < http:// www.planalto.gov.br/ccivil_03/LEIS/L4771.htm>. Acesso em: 18 jul. 2014.

CÂMARA, G. et al. SPRING: Integrating remote sensing and GIS by object-oriented data modelling. Computers \& Graphics, v. 20, n. 3, p. 395-403, may/jun. 1996. Disponível em: < http://www.academia.edu/510100/ SPRING_Integrating_remote_sensing_and_GIS_by_object-oriented_data_modelling >. Acesso em: 10 jun. 2104.

CAMPOS, F. L. M. Áreas de preservação permanente: efetividade da legislação e novas propostas para gestão ambiental territorial. 2009. 155f. Dissertação (Mestrado) - Engenharia Ambiental, Instituto Federal Fluminense, Macaé, 2009. Disponível em:< http://ppea.iff.edu.br/prod-cientifica/2009/Fabio\%20Luiz\%20 Macao\%20Campos.pdf/view>. Acesso em: 04 jul. 2014. 
CONAMA, Resolução no 303, de 20 de março de 2002. Complementada pela Resolução no 302/02; Alterada pela Resolução n ${ }^{\circ}$ 341/03 (acrescenta novos considerandos); Revoga a Resolução no 4/85 e dispõe sobre parâmetros, definições e limites de Áreas de Preservação Permanente. Diário Oficial [da República Federativa do Brasil], Brasília, 20 de mar. 2002. Disponível em: < http://www.mma.gov.br/port/conama/legislacao/ CONAMA_RES_CONS_2002_303.pdf>. Acesso em: 20 jul. 2014.

CONAMA, Resolução no 369, de 28 de março de 2006. Complementada pela Resolução no 302/02; Dispõe sobre os casos excepcionais, de utilidade pública, interesse social ou baixo impacto ambiental, que possibilitam a intervenção ou supressão de vegetação em Área de Preservação Permanente - APP. Diário Oficial [da República Federativa do Brasil], Brasília, 28 de mar. 2006. Disponível em: < http://www.mma.gov.br/port/conama/ legislacao/CONAMA_RES_CONS_2006_369.pdf>. Acesso em: 22 jul. 2014.

CORTIZO, S. Topo de morro na Resolução CONAMA n 303. (2007). Disponível em:

http://www.dcs.ufla.br/site/_adm/upload/file/slides/matdispo/geraldo_cesar/topo_de_morro.pdf>. Acesso em: 03 Jun.2014.

COSTA, D. S. M. As potencialidades da região semiárida do Norte de Minas Gerais: Análise do Centro de Estudos de Convivência com o Semiárido. In: Encontro Nacional dos Geográfos, XVI., 2010. Porto Alegre. Anais... Porto Alegre: AGB, 2010. p. 1-10. Disponível em: < file:///C:/Users/Home/Downloads/download(529)\%20 (3).PDF>. Acessado em: 12 de jun. 2014.

FAHRIG, Lenore. 2009. Effects of habitat and landscape fragmentation on humans and biodiversity in densely populated landscapes. Journal of Environmental Management. v. 90, n. 10, p. 2959-2968, jul. 2009. Disponível em: < http://www.sciencedirect.com/science/article/pii/S0301479709001583>. Acesso em: 10 jul. 2014.

GUIMARÃES, F. S.; CARVALHO, G. A. Determinação de áreas de preservação permanente no município de Moeda - MG, utilizando bases de diferentes escalas topográficas. Caderno de Geografia, v.23, n.39, p. 22-43, jan.-jun. 2013. Disponível em: <http://periodicos.pucminas.br/index.php/geografia/article/view/3960/4968>. Acesso em: 27 jun. 2014.

HOTT, M. C. et al. Um método para a determinação automática de áreas de preservação permanente em topos de morros para o Estado de São Paulo. In: Simpósio Brasileiro de Sensoriamento Remoto, XII., 2005, Goiânia. Anais... Goiânia: INPE, 2005. p. 3061-3068. Disponível em: < http://www.cnpm.embrapa.br/publica/ download/newsdownload/artigos_resumos\%20anais\%20eventos/apc_12sbsr05_umetodo_hott.pdf $>$. Acesso em: 15 jul. 2014.

et al. Método para a determinação automática de áreas de preservação permanente em topos de morros para o Estado de São Paulo, com base em geoprocessamento. Campinas: Embrapa Monitoramento por Satélites. 32 p. 2004. Disponível em:

<http://www.cnpm.embrapa.br/publica/download/doc34_AAAPTM04.pdf>. Acesso em: 23 de Jun. de 2014.

IBGE, INSTITUTO BRASILEIRO DE GEOGRAFIA E ESTATÍSTICA. Cidades@. Rio de Janeiro: IBGE, 2010. Disponível em: < <ttp://cidades.ibge.gov.br/xtras/ perfil.php?lang=\&codmun=314290\&search=minas-gerais $\mid$ monte-azul>. Acesso em: 18 jun. 2014.

INSTITUTO BRASILEIRO DE GEOGRAFIA E ESTATÍSTICA. Mapa dos Biomas continentais do Brasil. Rio de Janeiro: IBGE, 2004. Disponível em: < ftp://ftp.ibge.gov.br/Cartas_e_Mapas/Mapas_Murais/>. Acesso em: 26 jun. 2014.

IEF, Instituto Estadual de Florestas. Decreto [s.n]. de 28 de março de 2007. Cria o Parque Estadual Caminho dos Gerais, nos Municípios de Espinosa, Gameleiras, Mamonas e Monte Azul e dá outras providências. Diário Oficial [da República Estadual de Minas Gerais], Belo Horizonte, 28 mar. 2007. Disponível em: < http://ief. 
mg.gov.br/images/stories/portariaseleis/decreto_caminho_dos_gerais.pdf>. Acesso em: 14 jul. 2014.

KNAUER, L. G. et al. PROGRAMA GEOLOGIA DO BRASIL Contrato CPRM-UFMG Nº. 059/PR/05: Monte Azul- SD.23-Z-D-II, escala 1:100.000: nota explicativa. Minas Gerais: UFMG/CPRM, 2007. Disponível em: < http://www.cprm.gov.br/publique/media/rel_mantena.pdf>. Acesso em: 19 jul. 2014.

LIMA, F. A. et al. Delimitação das Áreas de Preservação Permanente em Topo de Morro. Estudo de Caso: Sub -Bacia do Rio Canoas, Montes Claros - MG. In: Simpósio Regional de Geoprocessamento e Sensoriamento Remoto, VI., 2012, Aracaju. Anais... Aracaju: UFS, 2012. p. 1-5. Disponível em: < http://www.cvmn.com. br/HTML/Arquivos/Artigos/00220_030248.pdf >. Acesso em: 04 jun. 2014.

MARTINS, S. L. et al. Análise multitemporal por imagem TM do uso e ocupação do solo na região nordeste da rodovia BR-319. In: Simpósio Brasileiro de Sensoriamento Remoto, XVI., 2013, Foz do Iguaçu. Anais... Foz do Iguaçu: INPE, 2013. p. 1782-1789. Disponível em: <http://www.dsr.inpe.br/sbsr2013/files/p0902.pdf>. Acesso em: 12 jun. 2014.

MOREIRA, F. M. S. et al. Biodiversidade do Solo em Ecossistemas Brasileiros. Editora UFLA. Lavras, 2008, 768p.

NERY, C. V. M. et al. Aplicação do Novo Código Florestal na Avaliação das Áreas de Preservação Permanente em Topo de Morro na Sub-Bacia do Rio Canoas no Município de Montes Claros/MG. Revista Brasileira de Geografia Física, v. 6, n. 6, p. 1673-1688, nov. 2013 .Disponível em: <http://www.revista.ufpe.br/rbgfe/ index.php/revista/article/view/633/500>. Acesso em: 16 jun. 2014.

ODUM, E. P. Ecologia. Editora Guanabara Koogan S. A. Rio de Janeiro, 1998. 434p.

OLIVEIRA, M. Z. do. et al. Delimitação de Áreas de Preservação Permanente: Um estudo de caso através de imagem de satélite de alta resolução associada a um sistema de informação geográfica (SIG). In: Simpósio Brasileiro de Sensoriamento Remoto, XIII., . 2007, Florianópolis. Anais... Florianópolis: INPE, 2007. p. 4119-4128. Disponível em: < http://marte.dpi.inpe.br/col/dpi.inpe.br/sbsr@80/2006/11.14.21.53/ doc/4119-4128.pdf >. Acesso em 02 jul. 2014.

PONZONI, F. J. et al. Sensoriamento remoto da vegetação. $2^{\mathrm{a}}$ edição atualizada e ampliada. $2^{\mathrm{a}}$. ed. São Paulo: Oficina de textos, 159 p, 2012.

REIS, A. A. dos. et al. land use and occupation analysis of permanent preservation areas in Lavras County, MG. Ciênc. agrotec., v. 36, n. 3, p. 300-308, maio/jun., 2012. Disponível em: < http://www.scielo.br/pdf/cagro/ v36n3/05.pdf>. Acesso em: 07 jul. 2014.

SOUSA, D. V. de. et al. Utilização de geoprocessamento para emarcação de áreas de preservação permanente, em uma micro bacia

do Rio Pomba, no município de Cataguases (MG). Geoambiente On-line, n.8, p. 37-48, jan.-jun. 2007. Disponível em: <http://revistas.jatai.ufg.br/index.php/geoambiente/article/view/52/45\#.U_CnDPldXrI>. Acesso em: 16 jun. 2014.

VALERIANO, M. de M. Modelo digital de variáveis morfométricas com dados SRTM

para o território nacional: o projeto TOPODATA. In: Simpósio Brasileiro de Sensoriamento Remoto, XII., 2005, Goiânia. Anais... Goiânia: INPE, 2005. p.3595-3602. Disponível em: < http://marte.dpi.inpe.br/ col/1tid.inpe.br/sbsr/2004/10.29.11.41/doc/3595.pdf>. Acesso em: 25 jun. 2014.

VALLE JUNIOR, R. R. do. et al. Diagnóstico das áreas de preservação permanente na microbacia hidrográfica do Corrego Jataí. Revista Caatinga, v. 24, n. 3, p. 153-157, jul.-set. 2011. Disponível em: <http:// 
periodicos.ufersa.edu.br/revistas/index.php/sistema/article/view/1965/4749>. Acesso em: 19 jul. 2014.

WEISS, R. et al. Identificação da fragilidade ambiental quanto a enchentes na cidade de Santa Maria-RS, por geotecnologias. In: Simpósio Brasileiro de Recursos Hídricos, XX., 2012, Bento Gonçalves. Anais... Bento Gonçalves: ABRH, 2012. p. 1-8. Disponível em: < http://www.abrh.org.br/SGCv3/UserFiles/Sumarios/056eea96acf6a2fe02dcc0c27bb5977_5736407f45fbd621bd6590fbfd3fe778.pdf>. Acesso em: 17 jul. 2014.

ZEE, Zoneamento Ecológico Econômico. ZEE - MG. Disponível em: <http://geosisemanet.meioambiente. mg.gov.br/zee/>. Acesso em 25 de Jul. de 2013. 